\title{
Decreased glutathione content and glutathione S-transferase activity in red blood cells of coal miners with early stages of pneumoconiosis
}

\author{
Chris T A Evelo, Robert P Bos, Paul J A Borm
}

\begin{abstract}
Blood samples of miners heavily exposed to coal dust were examined for changes in glutathione S-transferase (GST) activity. Decreased GST activity was found in red blood cells of subjects with early stages of coal workers' pneumoconiosis (International Labour Office classification 0/1-1/2) when compared with control miners. At further progression of coal workers' pneumoconiosis $(\geqslant 2 / 1)$, the activity of GST was not different from controls. In the same group with moderate coal workers' pneumoconiosis a decrease in GSH in red blood cells occurred. Decreases in GST activity in early stages of coal workers' pneumoconiosis, as well as the decreases in glutathione peroxidase (GPx) activity and in GSH concentrations reported earlier, ${ }^{1}$ may originate from damage caused by reactive oxygen species. These changes might imply an impairment of the detoxification capacity for electrophilic and oxidative compounds during this stage of the disease.
\end{abstract}

(British fournal of Industrial Medicine 1993;50:633-636)

Lung fibrosis related to the inhalation of dusts containing toxic particles such as silica or asbestos is a serious occupational hazard. It is well known that during the immune defence against dust particles, reactive oxidant species are secreted by various types of inflammatory cells with alveolar macrophages playing a key part in this process. ${ }^{23}$ The lung tissue possesses an elaborate defence mechanism to detoxify reactive oxidant species, constituted by a set of antioxidant enzymes such as

Department of Pharmacology (Toxicology section), University of Limburg, PO Box 616, $6200 \mathrm{MD}$ Maastricht, The Netherlands

C T A Evelo

Department of Toxicology, University of Nijmegen, PO Box 9101, $6500 \mathrm{HB}$ Nijmegen, The Netherlands

R P Bos

Department of Health Risk Analysis and Toxicology, University of Limburg, PO Box 616, $6200 \mathrm{MD}$ Maastricht, The Netherlands

P J A Borm superoxide dismutase and glutathione peroxidase (GPx) and low-molecular weight compounds such as glutathione (GSH) acting as a substrate for GPx and glutathione S-transferase (GST) or as direct radical scavengers. Also, antioxidants localised in erythrocytes are involved in the antioxidant protection of the lung, ${ }^{45}$ acting as circulating antioxidant carriers.

Previously, we showed ${ }^{167}$ that antioxidant enzymes and GSH in erythrocytes are affected at different stages of pneumoconiosis in coal workers or silicotic patients and in lung tissue of rats exposed to silica ${ }^{8}$; GSH concentration and GST activity were also found to be affected after occupational exposure to reactive compounds ${ }^{910}$ and in situations involving reactive oxidant species stress such as smoking ${ }^{10}$ and heavy exercise. ${ }^{11}$ This paper presents the results of GSH determinations and GST analyses with an activity assay and enzyme linked immunosorbent assay (ELISA) in red blood cells of a cohort of coal miners previously investigated by our research group. ${ }^{1}$

\section{Materials and methods}

SUBJECTS

Ninety one coal miners, all heavily exposed to coal dust underground at the coal face for at least 12 years, were selected from the Belgian coal mining industry pits (Kempense Steenkolenmijnen). Blood samples were taken and treated as described previously. ${ }^{1}$ Control miners $(n=58)$ and miners with coal workers' pneumoconiosis $(n=33)$ were matched for exposure and age at which they started work. In this study persons with the classification $0 / 1,1 / 0,1 / 1$, and $1 / 2^{12}$ were gathered in group 2 ( $n=19)$; persons with classification $2 / 1$ and higher in group $3(n=14)$; control miners constituted group 1 .

\section{ANALYTICAL METHODS}

Chemicals

The chemicals used were: rabbit polyclonal antibodies against GST $\pi$ (Medlabs; Dublin, Ireland), swine anti-rabbit IgG antibodies conjugated to horse radish peroxidase and orthophenylenediamine (OPD) (Dakopatts; Copenhagen, Denmark), 5,5'-dithiobis-(2-nitrobenzoic acid) (E 
Merck; Darmstadt, Germany). Reduced glutathione (Boehringer Mannheim; Mannheim, Germany), 1-chloro 2,4-dinitrobenzene (CDNB), dithiotreitol, GST $\pi$ from human placenta, and tween 20 (Sigma; St Louis, USA). All other chemicals were of analytical quality. Only microfiltered deionised water was used.

\section{Determination of blood GSH}

Total GSH concentration was determined with the cyclic oxidation reduction method essentially as described by Anderson. ${ }^{13}$

\section{Assays for GST}

Activity of GST (EC 2.5.1.18) was determined by a modification ${ }^{11}$ of the method described by Habig and Jacoby, ${ }^{14}$ lysing the erythrocytes by addition of three volumes of water containing $1.4 \mathrm{mmol} \cdot 1^{-1}$ neutral DTT, centrifugation, and measurement of the activity towards CDNB. A Cary 118 spectrophotometer was used in auto slit mode with the gain adjusted to $2 \cdot 5$.

For the competitive ELISA, Costar flat bottom 96 well EIA plates (Data Packaging Corporation; Broadway, MA, USA) were coated overnight at $4^{\circ} \mathrm{C}$ with $200 \mu \mathrm{l}$ phosphate buffered $\left(10 \mathrm{mmol}^{\cdot} \mathrm{1}^{-1}\right)$ saline of $\mathrm{pH} 7 \cdot 2$ containing $11 \mu \mathrm{U}$ GST $\pi$ from human placenta per well. Each well was washed three times with $200 \mu \mathrm{l}$ ELISA buffer (10 mmol $\cdot 1^{-1}$ sodium phosphate with $0.5 \mathrm{~mol} \cdot 1^{-1}$ sodium chloride and $0 \cdot 1 \%(\mathrm{v} / \mathrm{v})$ tween-20) of $\mathrm{pH}$ $7 \cdot 2$. This and all further steps were performed at room temperature. To each well $50 \mu \mathrm{l}$ of the antigen solution (haemolysate) and $150 \mu \mathrm{l}$ antibodies against GST $\pi$ diluted 2250-fold with ELISA buffer were added. After two hours of incubation the wells were washed three times with ELISA buffer and incubated for one hour with $200 \mu \mathrm{l}$ horse radish peroxidase labelled anti-IgG diluted 1500-fold with ELISA buffer. After another three washes with ELISA buffer $100 \mu \mathrm{l}$ of a 100 mmol $\cdot 1^{-1}$ citrate-phosphate buffer $(\mathrm{pH} 5 \cdot 0)$ containing $0.67 \mathrm{mg} / \mathrm{ml} \mathrm{OPD}$ and $0.0125 \%(\mathrm{w} / \mathrm{v}) \mathrm{H}_{2} \mathrm{O}_{2}$ were added to each well. After exactly 15 minutes the enzymatic reaction was stopped by addition of $150 \mu \mathrm{l} 1 \mathrm{M}$ sulphuric acid. The extinctions at 492 $\mathrm{nm}$ were read with a multiscan interfaced to a MINC computer.

Reference data for the quantification of the ELISA results were obtained with GST $\pi$ from human placenta. Known quantities of this enzyme - expressed in activity units-were tested in the competitive ELISA assay. The results were fitted to the general logistic function: ${ }^{15}$

$$
\mathrm{Y}=\frac{\mathrm{a}-\mathrm{d}}{1+\left(\frac{\mathrm{C}}{\mathrm{EC}_{50}}\right)^{s}}+d
$$

where $Y$ is the response; $C$ the concentration of the antigen; $a$ the response when $C=0 ; d$ the response for "infinite" concentrations of antigen; $E C_{50}$ the antigen concentration resulting in a response half way between $a$ and $d$; and $s$ is a slope factor that corresponds to the slope of the logit-log plot, when $C$ is plotted in terms of natural logarithms. For curve fitting the NLIN procedure from the SAS package was used with the DUD method for nonlinear regression. ${ }^{16}$ The response was expressed as a fraction of the maximum extinction, found without addition of antigen, $E=Y / a$.

The haemoglobin concentrations in the erythrocytes were determined with the haemoglobin cyanide procedure. ${ }^{17}$

\section{STATISTICAL EVALUATIONS}

Analytical results were coupled to previous data on this cohort in a database. Correlations between variables were studied using STATGRAPH 3.01 statistical package. Differences between variables in separate groups were evaluated with the Wilcoxon 2 sample test.

\section{Results}

The table shows the mean values and standard deviations (SDs) of GSH concentrations, GST activity towards CDNB and GST content as determined by competitive ELISA in the blood of the control miners and the two groups of miners with coal workers' pneumoconiosis. No effect of smoking was seen on any variable mentioned. Concentrations of GSH were determined previously. ${ }^{1}$ Repeated analyses of the frozen samples used for the GST determinations did not show significant differences from the original values. Therefore, the original data rearranged for the current purpose are listed in the table. Both GSH concentration and GST activity were decreased in group 2, the workers with moderate forms of coal workers' pneumoconiosis. In group 3 such a decrease was not found. The GST protein content showed a tendency to follow the GST activities, although the decrease in group 2 did not attain statistical significance.

\section{Discussion}

Our data show that, as well as GSH, erythrocyte GST activity is decreased in subjects with early stages of pulmonary fibrosis $(0 / 1-1 / 2)$ when compared with control miners. At further progression of coal workers' pneumoconiosis $(2 / 1+)$, however, erythrocyte activity was not different from controls. In the same group with moderate coal workers' pneumoconiosis, a decrease in GSH in erythrocytes occurs. Previously, we reported an increase in total GPx activity in the same workers at early stages of the disease ${ }^{1}$ and in rat lung homogenates after in vivo exposure to silica or 
Glutathione (GSH) concentrations, glutathione S-transferase (GST) activity towards CDNB, and glutathione S-transferase protein content determined by ELISA in red blood cells of coal workers

\begin{tabular}{|c|c|c|c|c|}
\hline & $\begin{array}{l}\text { Control } \\
\text { miners }(O / 0) \\
\text { Mean }(S D)\end{array}$ & $\begin{array}{l}\text { Group } 2 \\
C W P(0 / 1-1 / 2) \\
\text { Mean }(S D)\end{array}$ & $\begin{array}{l}\text { Group } 3 \\
C W P(\geq 2 / 1) \\
\text { Mean }(S D)\end{array}$ & p Value \\
\hline $\begin{array}{l}\text { GSH } \\
\left(\mathrm{mmol} \cdot \mathrm{g} \mathrm{Hb}^{-1}\right) \\
\text { GST (CDNB) } \\
\text { (U.g Hb } \mathrm{Hb}^{-1} \text { ) } \\
\text { GST (ELISA) } \\
\text { (equiv U.g Hb } \\
\text { (e) }\end{array}$ & $\begin{array}{l}3.97(0.08) \\
n=58 \\
2 \cdot 99(1 \cdot 36) \\
n=45 \\
2.46(1.93) \\
n=34\end{array}$ & $\begin{array}{l}3 \cdot 62(0 \cdot 14) \\
\mathrm{n}=19 \\
2 \cdot 31(1 \cdot 09) \\
\mathrm{n}=9 \\
1 \cdot 92(0 \cdot 90) \\
\mathrm{n}=6\end{array}$ & $\begin{array}{l}3 \cdot 98(0 \cdot 46) \\
\mathrm{n}=14 \\
3 \cdot 37(1 \cdot 14) \\
\mathrm{n}=10 \\
2 \cdot 54(1 \cdot 39) \\
\mathrm{n}=7\end{array}$ & $\begin{array}{l}0.016 \\
0.061\end{array}$ \\
\hline
\end{tabular}

p Values are for group $2 v$ control miners (Wilcoxon 2 sample test).

asbestos. ${ }^{8}$ We think that the decrease in GSH concentration and GST activity is caused by excessive release of reactive oxidant species by alveolar macrophages and neutrophils in the lung tissue. A decrease in GST activity cannot be the result of decreased GSH concentrations during determinations, as saturating concentrations of GSH (1 $\left.\mathrm{mmol} \cdot \mathrm{1}^{-1}\right)$ are added in the assay. Moreover, there is no (negative) correlation between GSH content and GST activity of the blood samples. Combined with our data obtained with the ELISA on GST in erythrocytes (which tended to decrease in the same group) we conclude that a fraction of GST is damaged, possibly by oxidation of $\mathrm{SH}$ sites. The decrease in available GST activity plus the fact that GST activity is GSH dependent, might imply that in vivo functioning of the enzyme is affected rendering these subjects more susceptible to damage resulting from lipid peroxidation or from coexposure to electrophilic compounds. Various mineral fibres were reported to inhibit GST activity in the cytosol of rat lung homogenates after in vitro and in vivo exposure, whereas phase 1 reactions were increased at advanced stages of the disease. ${ }^{18}$ An induction of phase I enzymes in advanced stages of fibrosis might further aggregate the accumulation of activated metabolites in the lung.

Previously, we argued that the restoration of erythrocyte GSH content to control values in miners with coal workers' pneumoconiosis beyond $2 / 1$ is caused by a hepatic efflux of GSH. ${ }^{1}$ We found comparable phenomena for GST in previously untrained subjects. After moderate running training (up to 60 minutes after 20 weeks) GST activity and GSH concentrations in erythrocytes were both increased. ${ }^{11}$ After heavy training (up to 90 minutes after 40 weeks) GSH values returned to normal and GST was substantially increased. Increases in GST protein content in erythrocytes can be the result of increased protein synthesis during erythrocyte proliferation, or, less likely, of increased longevity of the protein itself. Increases in GST content were also found in smokers. ${ }^{10}$ Here lower specific activities and equal total activities were found. This too might be a result of compensatory GST synthesis. Thus GST activity in coal miners with coal miners' pneumoconiosis $>2 / 1$ could remain at normal values due to compensation of inactivation by extra protein synthesis during erythrocyte proliferation. This extra synthesis could be triggered by inflammatory processes generating cytokine release in coal workers' pneumoconiosis ${ }^{19}$ or heavy exercise. Possibly the formation of lipid peroxides, reported to occur during exercise ${ }^{20}$ and in rats exposed to mineral fibres, ${ }^{21}$ could be an important factor in this respect. Lipid peroxides are known to be detoxified by GST, which shows selenium independent GPx activity. ${ }^{22}$

In conclusion, GST activity in erythrocytes is affected in early phases of coal workers' pneumoconiosis, possibly as a result of oxidative damage. Combined with our earlier findings (a decrease in GSH concentration and an increase of GPx activity), this might mean that detoxification of electrophilic compounds in these stages is impaired.

We thank Drs K Herberichs and JGP Peters of the Department of Toxicology from the University of Nijmegen for their assistance with the analyses.

1 Engelen JJM, Born PJA, Sprundel $M$ van, Lenaerts L. Blood anti-oxidant parameters at different stages of pneumoconiosis in coal workers. Environ Health Perspect 1990;84:165-72.

2 Bowden DH. Macrophages, dust and pulmonary diseases. Exp Lung Res 1987;12:89-107.

3 Sibille Y, Reynolds HY. Macrophages and polymorphonuclear neutrophils in lung defense and injury. Am Rev Respir Dis 1990;141:471-501.

4 Asbeck BS van, Hoidal J, Vercelotti GM, Schwartz BA, Moldow CF, Jacobs HS. Protection against lethal hyperoxia by tracheal insufflation of erythrocytes: role of red cell glutathione. Science 1984;277:756-8.

5 Toth KM, Clifford DP, Berger EM, White CW, Repine JE. Intact human erythrocytes prevent hydrogen peroxide-mediated damage to isolated perfused rat lungs and cultured bovine pulmonary artery endothelial cells. $\mathcal{f}$ Clin Invest 1984;74:292-5.

6 Borm PJA, Bast A, Wonters EFM, Slangen JJM, Swaen $\mathrm{GMH}$, Boorder Tj. de. Red blood cell anti-oxidant parameters in silicosis. Int Arch Occup Environ Health 1986;58:235-44.

7 Borm PJA, Engelen JJM, Palmen N, Buurman WA. Red blood cell anti-oxidants and monocyte tumor necrosis factor 
(TNF) in the pathogenesis of coul workers' pneumoconiosis. In: Sebastien P, ed. Mechanisms in occupational lung diseases, Colloque INSERM, 1991;203:161-7.

8 Janssen YMW, Marsh JP, Absher MP, Hemenway D, Vacek PM, Leslie KO, Borm PJA, Mossman BT. Expression of antioxidant enzymes in rat lungs after inhalation of asbestos or silica. F Biol Chem 1992;267:10625-30.

9 Brouwer EJ, Evelo CTA, Verplanke AJW, Welie RTH van, Wolff FA de. Biological effect monitoring of exposure to 1,3-dichloropropene: effects on liver and renal function and on glutathione conjugation. Br f Ind Med 1991;48:167-72.

10 Evelo CTA, Henderson PTh. Biological effect monitoring. Arch Toxicol Suppl 1992;15:268-77.

11 Evelo CTA, Palmen NGM, Artur Y, Janssen GME. Changes in blood glutathione concentrations, and in erythrocyte glutathione reductase and glutathione S-transferase activity after running training and after participation to contests. Eur f Appl Physiol 1992;64:354-8.

12 Parmeggiani L. International classification of pneumoconiosis. In: Parmeggiani L, ed. Encyclopedia of occupational health and safety. 3rd ed. Vol II. Geneva: International Labour Organisation, 1983:1733-41.

13 Anderson ME. Determination of glutathione and glutathione disulfide in biological samples. Methods Enzymol 1985;113: 548-55.

14 Habig WH, Jakoby WB. Assays for the differentiation of glu- tathione S-transferases. Methods Enzymol 1981;77:398-405.

15 De Lean A, Munson PJ, Rodbard D. Simultaneous analysis of families of sigmoidal curves: application to bioassay, radioligand assay and physiological dose-response curves. $\mathrm{Am} \mathcal{F}$ Physiol 1978;235:E97-E102.

16 Ralston ML, Jennrich RI. DUD, a derivative-free algorithm for nonlinear least squares. Technometrics 1978;20:7-14.

17 Kampen EJ van, Zijlstra WG. Determination of hemoglobin and its derivatives. Adv Clin Chem 1965;8:141-87.

18 Rahman Q, Khan SG, Ali S. Effect of crysotile asbestos on cytochrome P-450-dependent monooxygenase and glutathione-S-transferase activities in rat lung. Chem Biol Interact 1990;75:305-13.

19 Kelley J. Cytokines of the lung. Am Rev Respir Dis 1990;141: $765-88$.

20 Duthie GG, Robertson JD, Maugham RJ, Morrice PC. Blood antioxidant status and erythrocyte lipid peroxidation following distance running. Arch Biochem Biophys 1990;282:78-80.

21 Petruska JM, Leslie KO, Mossman BT. Enhanced lipid peroxidation in bronchoalveolar lavage of rats after inhalation of crocidolite asbestos. Free Radic Biol Med 1991;11:425-32.

22 Mannervik B, Danielson UH. Glutathione transferases-structure and catalytic activity. Critical Reviews in Biochemistry 1988;23:283-337.

Accepted 5 October 1992 